\title{
SOSIALISASI PEMANFAATAN KERAJINAN TANGAN MENGGUNAKAN STIK ES KRIM
}

\author{
Siti Husnul Hotima \\ Progam Studi Ilmu Administrasi Niaga \\ Sekolah Tinggi Ilmu Administrasi Pembangunan Jember \\ *Email: sitihusnulhotima@gmail.com
}

\begin{abstract}
ABSTRAK
Kerajinan adalah suatu karya seni yang proses pembuatannya menggunakan keterampilan tangan manusia. Biasanya hasil dari sebuah kerajinan dapat menghasilkan suatu hiasan cantik, benda dengan sentuhan seni tingkat tinggi dan benda siap pakai. Kerajinan Tangan adalah menciptakan suatu produk atau barang yang dilakukan oleh tangan dan memiliki fungsi pakai atau keindahan sehingga memiliki nilai jual. Kerajinan tangan yang memiliki kualitas tinggi tentu harganya akan mahal, jika kalia memiliki keterampilan dan berusaha untuk membuat suatu produk mungkin dengan kerajinan yang akan memiliki bisa menjadi suatu usaha yang menjanjikan. Menurut Kadjim (2011:10), kerajinan adalah suatu usaha yang dilakukan secara terus menerus dengan penuh semangat ketekunan kecekatan, kegigihan, berdedikasi tinggi dan berdaya maju yang luas dalam melakukan suatu karya. Setelah kita melihat beberapa pengertian kerjinanan, bisa mengetahui bahwa bahan produk kerajinan yang dihasilkan itu sangat unik. Kerajinan yang unik karena hasil dari proses pembuatan yang masih manual, yaitu masih menggunakan tangan manusia. Selain itu, produk kerajinan tangan juga pasti mempunyai harga tinggi, maka dari itu sudah seapututnya sebagai warga negara mampu menciptakan sebuah kerajinan, atau paling setidaknya produk kerajian asli Indonesia.

Kata kunci : Kerajinan, Karya, Produk
\end{abstract}




\section{A. ANALISIS SITUASI}

Seiring dengan bertambahnya kebutuhan manusia, banyak juga diciptakan pemuas atau pemenuhan kebutuhan manusia. Untuk itu munculah pabrik - pabrik industri sebagai pengolah bahan mentah kemudian diolah sedemikian rupa menjadi barang setengah jadi maupun bahan siap pakai, untuk selanjutnya akan dikonsumsi masyarakat. Dalam jumlah produksi yang sangat besar tiap harinya akan mengkasilkan sisa- sisa hasil proses pengolahan yang tidak terpakai.

Sampah tidak selamanya merepotkan kita, kini sampah bisa diubah menjadi barang yang berguna dan bernilai tinggi. Salah satunya adalah mengubah sampah stik es krim menjadi vas bunga, tempat tisu, kotak permen, miniature rumah atau yang lainnya. Stik es krim biasanya dipakai untuk ek krim ternyata mempunyai nilai seni yang tinggi jika diubah dan didaur ulang sehingga menyerupai benda yang diinginkan. Stik es krim yang biasa digunakan untuk membuat kesenian adalah stik yang panjang bukan yang pendek yang mempunyai lekukan.
Stik es krim yang panjang dan tidak memiliki lekukan akan mudah untuk dirangkai. Stik es krim seperti itulah yang akan kami pakai sebagai pembuatan kotak permen. Kotak permen dari stik es krim akan terlihat unik karena bahan dasar dan model yang dipilih dan dalam pembuatannya tidak sulit.

\section{B. TINJAUAN PUSTAKA}

Pengertian Kerajinan

Kerajinan adalah hal yang berkaitan dengan buatan tangan atau kegiatan yang berkaitan dengan barang yang dihasilkan melalui keterampilan tangan (kerajinan tangan)Kerajinan sering diartikan sebagai suatu seni yang sering disebut sebagai seni kriya.Seni kriya sendiri berasal dari kata Kriya yang berasal dari bahasa Sanskerta yang artinya perbuatan atau pekerjaan atau membuat. Sedangkan ahli seni lain menyebutkan kriya sebagai pekerjaan dalam hubungannya dengan ketrampilan tangan sebab menurutnya jika dibahasa Inggriskan menjadi craft, yang mempunyai arti energi atau kekuatan. Yang sering ditemui adalah pengertian seni kriya 
sebagai karya yang dihasilkan karena manusia mempunyai ketrampilan.

Kerajinan di sini bisa disebut sebagai kerajinan tangan, walaupun kita tentu yakin ada kerajian yang bisa dibuat oleh kaki. Kerajinan bisa mendapatkan sedikit bagian darii pengertian seni kriya. Kriya yang ternyata berasal dari bahasa tinggi di kerajaan Jawa dijalani oleh seseorang yang disebut sebagai empu. Sedangkan di kalangan di luar istana kriya dimanifestasikan menjadi kerajinan. Kalau kriya diampu oleh empu, maka kerajinan dilakukan oleh pandhe. Bedanya tidak hanya di situ. Dari sisi yang dihasilkan pun berbeda. Empu menghasilkan senjata, perhiasan, pernak-pernik bagi seua kalangan istana, sementara pandhe menghasilkan sabit, cangkul, pikulan, geriobak, gerabah, dan lainlain perlengkapan rakyat kebanyakan.

Dalam masa sekarang kerajinan bisa kita sangkut pautkan dengan komoditi perdagangan baik dalam negeri maupun luar negeri. Kerajinan sekarang tidak lagii merupakan benda utama untuk bekerja namun sudah menjadi benda pelengkap dalam kehidupan yang modern. Kerajinan sebagai hiasan dan barang pajangan. Cangkul atau sabit yang dulu dipakai bertani sekarang sudah digantkan dengan alat modern sehingga pacul dan arit tadi menjadi barang antik yang bagus jika digantung di dinding rumah. Tokotoko ditulisi banner jual barang antik, kerajinan tradisional, kerajinan antik, sisa eksport.

\section{URGENSI PROGRAM}

Sampah yang berserakan bukankah barang yang tidak berguna melainkan benda yang belum menjadi benda yang berguna. Agar sampah itu lebih berguna maka akan lebih baik jika sampah tersebut kita olah kembali menjadi barang yang berguna dan memiliki nilai jual tinggi. Stik es krim yang tidak berharga kini menjadi berharga karena bisa diolah menjadi berbagai macam benda yang berguna. Stik es krim itu sendiri jika dibentuk sekreatif mungkin akan terlihat unik dan memiliki nilai seni yang tinggi. Stik es krim tidak selamanya menjadi stik es krim. 
Seiring dengan bertambahnya kebutuhan manusia, banyak juga diciptakan pemuas atau pemenuhan kebutuhan manusia. Untuk itu munculah pabrik - pabrik industri sebagai pengolah bahan mentah kemudian diolah sedemikian rupa menjadi barang setengah jadi maupun bahan siap pakai, untuk selanjutnya akan dikonsumsi masyarakat. Dalam jumlah produksi yang sangat besar tiap harinya akan mengkasilkan sisa- sisa hasil proses pengolahan yang tidak terpakai.

Sampah tidak selamanya merepotkan kita, kini sampah bisa diubah menjadi barang yang berguna dan bernilai tinggi. Salah satunya adalah mengubah sampah stik es krim menjadi vas bunga, tempat tisu, kotak permen, miniature rumah atau yang lainnya. Stik es krim biasanya dipakai untuk es krim ternyata mempunyai nilai seni yang tinggi jika diubah dan didaur ulang sehingga menyerupai benda yang diinginkan. Stik es krim yang biasa digunakan untuk membuat kesenian adalah stik yang panjang bukan yang pendek yang mempunyai lekukan. Stik es krim yang panjang dan tidak memiliki lekukan akan mudah untuk dirangkai. Stik es krim seperti itulah yang akan kami pakai sebagai pembuatan tempat handphone. Tempat handphone dari stik es krim akan terlihat unik karena bahan dasar dan model yang dipilih dan dalam pembuatannya tidak sulit.

\section{TUJUAN DAN MANFAAT PROGRAM}

Program "Kreasi Seni Kerajinan Stik Es Krim" memiliki tujuan yaitu sebagai berikut:

Untuk mengetahui cara mengelola barang bekas seperti stik es krim menjadi sebuah kerajinan

Untuk meningkatkan kreativitas masyarakat

Untuk memberikan penghasilan tambahan bagi masyarakat.

\section{E. DESKRIPSI PROGRAM}

\section{E1. Bentuk Kegiatan}

Program "Kreasi Seni Kerajinan Stik Es Krim" memiliki dua kegiatan yaitu sebagai berikut: Sosialisasi program di tiga desa di Kecamatan Jenggawah, yaitu Desa Jatisari, Sruni dan Jatimulyo yang akan dilaksanakan pada Sabtu 14 
Mei 2019. Sosialisasi di Desa Jatisari dan Desa Sruni dilakukan dengan metode pemaparan dan diskusi kepada kader PKK dan Posyandu desa. Untuk sosialiasi di Desa Jatimulyo dilaksanakan dengan penyebaran pamlet kepada kelompok-kelompok masyarakat di desa.

Penyelenggaraan program pembagian stik es krim dilakukan terpusat di Desa Jatisari pada Senin 16 Mei 2019. Penyelenggaraan program secara terpusat di Desa Jatisari dilakukan dengan adanya aktivitas masyarakat yaitu "Program On The Spot" dari tim pelaksana.

\section{E2. Target Group}

Program "Kreasi Seni Kerajinan Stik Es Krim" ini merupakan program penyuluhan yang dilaksanakan dengan melibatkan kelompok-kelompok masyarakat yang ada di desa seperti Kader PKK, Kader Posyandu, Kelompok Pemuda dan Kelompok Keagamaan.

\section{E3.Target Pencapaian}

Program "Kreasi Seni Kerajinan Stik Es Krim" memiliki target pencapaian salah satunya:

Target pencapaian sosialisasi, adalah meningkatnya pemahaman dan ketertarikan masyarakat terhadap kreasi seni kerajinan stik es krim.

Target pencapaian pelatihan program adalah 45 pendaftar yang diasumsikan dari 3 desa terdapat masing-masing 15 pendaftar.

\section{F. PELAKSANAAN PROGRAM}

\section{F1. Pelaksanaan Sosialisasi}

Pelaksanaan sosialisasi dilaksanakan untuk meningkatkan pemahaman, kesadaran dan ketertarikan masyarakat terhadap kreasi seni kerajinan stik eskrim. Artinya, sosialisasi ini menjadi faktor pendukung utama untuk kesuksesan penyelenggaraan program pelatihan. Sosialisasi dilakukan dengan dua model yaitu temu warga dan model penyebaran pamflet.

\section{F2. Pelaksanaan Program}

Program "Kreasi Seni Kerajinan Stik Es Krim" dilaksanakan pada Senin, 16 Mei 2019 pukul 09.00-12.00 bertempat di 
balai desa Jatisari Kecamatan Jenggawah. Pendaftar sosialisasi tercatat sebanyak 46 orang. Dari 46 Orang tersebut, ternyata tidak semuanya hadir untuk sosialisasi, karena beberapa alasan, yaitu sebagai berikut:

Beberapa peserta tidak minat dalam kegiatan sosialisasi.

Beberapa peserta tidak bisa hadir dikarenakan sibuk bekerja.

Beberapa peserta tidak hadir tanpa alasan.

Pada pelaksanaan program berlangsung, peseta sosialisasi yang hadir akan diberikan materi terkait kreasi seni kerajinan stik es krim. Agar masyarakat memahami dan bisa membuat hasil dari kreasi seni stik es krim. Setelah peserta mengikuti sosialisasi, panitia akan memberikan sejumlah bahan perlengkapan stik es krim dan sebagainya kepada masyarakat secara rata.

Dari pencapaian pelaksanaan program tersebut, diharapkan masyarakat memahami dan mengoptimalkan pemanfaatan potensi kerajinan stik eskrim. Diharapkan untuk kedepannya setelah pelaksanaan sosialisasi ini, masyarakat dapat meningkatkan pendapatan dan kesejahteraan masyarakat

\section{G. PENUTUP}

Demikian laporan pengabdian kepada masyarakat dengan tema "Sosialisasi Kreasi Seni Kerajinan Stik Es Krim" ini disampaikan. Atas perhatian dan kerjasamanya disampaikan terima kasih.

\section{DAFTAR PUSTAKA}

Abas, Tati (2011). Seni Kerajinan Tangan. Bandung: Jurusan Pendidikan Kesejahteraan Keluarga, Universitas Pendidikan Indonesia

Anonim. (2014). Cara Membuat Bunga Dari Kulit Jagung. Diakses dari :http://becreativeina.blogs pot.co.id/2014/08/caramembuat-bunga-darikulitjagung.html

Ajim, Nanang (2015) Produk Kerajinan Limabah Sisik Ikan. Diakses :http://www.mikirbae 
.com/2015/05/produk-

kerajinan-limbah-sisik-

ikan.html

Arikunto, Suharsimi (1997).

Prosedur Penelitian Suatu

Pendekatan Praktek. Jakarta:

PT. Rineka Cipta (2006).

Prosedur Penelitian Suatu

Pendekatan Praktek. Ed

Revisi VI. Jakarta: PT. Rineka

Cipta

Arsyad, Azhar.(2013). Media

Pembelajaran. Jakarta:

Rajawali Mustain, Choirul

(2015). Bisnis Limbah.

Diakses

http://limbahitubisnis.blogspot

.co.id/

Dimas (2014). Kerajinan Yang Terbuat Dari Batok Kelapa.

Diakses:

http://www.jejaring.web.id/ke

rajinan-yang-terbuat-dari-

batok-kelapa/

Enen, Wardana (2004) . Membuat Aneka Kreasi Berbahan Sisik Ikan. Jakarta : Kawan Pustaka

Marno.(2014).Strategi,Metode,Dan

Teknik Mengajar. Yogyakarta:
AR-RUZZ Media Migristine, Ririn. (2007). Pengolahan Sampah Plastik. Bandung: Angkasa

Mulyasa. (2012). Praktik Penelitian Tindakan Kelas. Bandung : Remaja Rosdakarya. 